\title{
Grayscale histogram analysis to study the echogenicity and echotexture of the walls of the common carotid arteries of horses and mules
}

\author{
Jéssica L. Fogaça ${ }^{2}$ (D), Michel C. Vettorato ${ }^{3}$, José Nicolau P. Puoli-Filho ${ }^{3}$, \\ Marco A.R. Fernandes ${ }^{3}$ and Vânia Maria V. Machado ${ }^{3 *}$ (D)
}

\begin{abstract}
Fogaça J.L., Vettorato M.C., Puoli-Filho J.N.P., Fernandes M.A.R. \& Machado V.M.V. 2019. Grayscale histogram analysis to study the echogenicity and echotexture of the walls of the common carotid arteries of equines and mules. Pesquisa Veterinária Brasileira 39(3):221-229. Departamento de Reprodução Animal e Radiologia Veterinária, Faculdade de Medicina Veterinária e Zootecnia, Universidade Estadual Paulista, Rua Prof. Dr. Walter Mauricio Correra s/n, Rubião Junior, Botucatu, SP 18618-970, Brazil. E-mail: vaniamvm@fmvz.unesp.br

Visual inspection of ultrasound examination for assessment of echogenicity and echotexture of blood vessel tissues is a technique routinely used in medical practice in humans. However, simple visual inspection can lead to poor quality diagnoses and errors. The use of grayscale histogram (GSH) analysis has proved to be an efficient technique to quantify the region of interest, allowing minimization of image interpretation errors. This study aimed to evaluate and compare the echogenicity and echotexture of the walls of the common carotid arteries of healthy female horses and mules using the GSH technique and correlate them with age, body mass, and vessel diameters. B-mode ultrasound examinations were performed in the left and right common carotid arteries in three regions (cranial, middle, and caudal) in 11 horses and 11 healthy mules. The GSH of the animals showed heterogeneous walls, but did not differentiate statistically between female horses and mules. The Mean variable of the middle right, middle left and caudal right sides showed differences, more significant in the mules. On the middle right side, the Min variable was different, higher in the mules. On the middle and caudal left side, the variables Max and Mode showed higher values in the mules. For the mules, the age factor presented negative correlation with the Mean, Mode,, Mode(Count), and Mode(Count)/Count(\%) variables, and the body mass factor presented negative correlation with the Mode, Mean and Max variables. For the female horses, the body mass factor showed positive correlation with the Mean and Mode variables. Echogenicity of the carotid artery walls differed between female horses and mules, whereas echotexture was heterogeneous and statistically similar among the animals. The age and body mass factors inversely influenced the echogenicity of the mules, but were not significant in the female horses, in which only the body mass factor positively influenced echogenicity.
\end{abstract}

INDEX TERMS: Grayscale histogram, echogenicity, echotexture, carotid arteries, horses, mules, histogram analysis, ultrasonography, wall of blood vessels, equines, quantitative analysis, morphology.

\footnotetext{
${ }^{1}$ Received on September 14, 2018.

Accepted for publication on September 24, 2018.

${ }^{2}$ Departamento de Reprodução Animal e Radiologia Veterinária, Faculdade de Medicina Veterinária e Zootecnia, Universidade Estadual Paulista "Julio de Mesquita Filho" (Unesp), Rua Prof. Dr. Walter Mauricio Correra s/n, Rubião Junior, Botucatu, SP 18618-970, Brazil. *Corresponding author: vaniamvm@fmvz.unesp.br

${ }^{3}$ Faculdade de Medicina Veterinária e Zootecnia, Universidade Estadual Paulista "Julio de Mesquita Filho" (Unesp), Rua Prof. Dr. Walter Mauricio Correra s/n, Rubião Junior, Botucatu, SP 18618-970, Brazil.
}

RESUMO.- [Análise por histograma em escala de cinza para estudo da ecogenicidade e ecotextura das paredes das artérias carótidas comuns de equinos e muares.] A técnica de avaliação da ecogenicidade e ecotextura dos tecidos dos vasos sanguíneos por inspeção visual do exame de ultrassonografia, já é uma prática da rotina médica em humanos. No entanto, a simples visualização manual pode induzir à erros e diagnósticos de pouca qualidade. $\mathrm{O}$ uso 
de análise por histograma em escala de cinza (HEC) tem se demostrado uma eficiente técnica para quantificar a região avaliada, permitindo minimizar erros de interpretação. 0 objetivo deste trabalho foi avaliar e comparar a ecogenicidade e ecotextura das paredes das artérias carótidas comuns das fêmeas equina e muares hígidos usando a técnica de HEC, e correlacioná-las com a idade, massa corpórea e diâmetros dos vasos. Exames de ultrassonografia modo-B foram realizados nas artérias carótidas comuns esquerda e direita em três regiões (cranial, médio e caudal) em 11 fêmeas equina e 11 muares hígidos. O HEC dos animais apresentou paredes heterogêneas, mas não diferenciaram estatisticamente entre fêmeas equinas e muares. A variável Mean do lado direito médio, esquerdo médio e caudal apresentou diferenças, sendo maiores nos muares. No lado direito médio, o Min foi diferente, sendo superior nos muares. Já para o lado esquerdo médio e caudal, as variáveis Max e Mode apresentaram valores maiores nos muares. Para os muares, o fator idade apresentou correlação negativa com Mean, Mode, Mode (Count) e Mode(Count)/Count (\%) e o fator massa corpórea apresentou correlação negativa com Mode, Mean e Max. Para as fêmeas equinas o fator massa corpórea apresentou correlação positiva com Mean e Mode. A ecogenicidade das paredes das artérias carótidas diferiram entre fêmeas equina e muares, já a ecotextura foi heterogênea e semelhante estatisticamente entre os animais. A idade e a massa corpórea influenciaram inversamente na ecogenicidade dos muares, enquanto que nas fêmeas equina a idade não foi significativa, apenas a massa corpórea influenciou positivamente com a ecogenicidade.

TERMOS DE INDEXAÇÃO: Histograma, ecogenicidade, ecotextura, artérias carótidas, equinos, muares, ultrassonografia, parede dos vasos sanguíneos, equídeos, análise quantitativa, morfologia.

\section{INTRODUCTION}

Visual inspection of ultrasound (US) examination is insufficient to accurately determine the echogenicity and echotexture of the evaluated tissues. Consequently, techniques that enable quantification of the region of interest (ROI) have been created, thus allowing minimization of image interpretation errors (Maeda et al. 1998, Silva et al. 2015, Dantas et al. 2016, Mendonça 2017).

Grayscale histogram (GSH) assesses the frequency distribution in gray-levels and the quantification that forms the image of the ROI (Maeda et al. 1998, Lee et al. 2006, Vescovi et al. 2009).

GSH has been used to evaluate the echogenicity and echotexture of several organs, presenting important clinical and academic applicability. The study of a tissue shows apparent density in the two-dimensional mode (B-mode), which is altered by pathological conditions, providing the examiner with a subjective analysis of the ROI (Rosenfield et al. 1980, Queiroz \& Gomes 2001, Armstrong et al. 2003).

GSH has been used in human medicine (Wohlin et al. 2009, Lee 2010, Mendonça 2017) to assess carotid artery walls in patients with atherosclerotic plaques deposited in the intima and media layers, because carotid artery intima-media complex thickening is considered a marker of early atherosclerosis, and US examination enables visual inspection of the normal-thickness vessel wall. However, there may be variation in echotexture and echogenicity not observed by the specialist during examination, and GSH may add information to diagnosis (Lind et al. 2008, Wohlin et al. 2009, Anderson et al. 2009, Lee 2010, Sarmento et al. 2014).

Deposition of atherosclerotic plaques in the carotid arteries is not as frequent in animals as it is in humans (Rosa et al. 2003, Ribeiro \& Shintaku 2004, Wohlin et al. 2009). Nevertheless, there are reports of plaque deposition in dogs (Hess et al. 2003) and horses (Aguiar et al. 2014), and US examination enables the subjective evaluation of this disease; however, in situations such as those previously mentioned, just like in humans, (Baroncini et al. 2006), GSH could complement the assessment.

Mules are not considered horse, since they are the result of the crossing between horses and donkeys (Souza et al. 2013), and although these two species share common ancestry, they present significant morphological differences. Therefore, it is expected that mules showed some anatomo-physiological differences in relation to horses; however, there are few studies on equines in the literature, which produces a deficit of information (Burnhan 2002, Alsafy et al. 2008, Smith 2009). Studies including both of these species, especially addressing the common carotid arteries, are necessary, as these vessels are directly responsible for the flow of rich oxygen to the brain (Rosa et al. 2003, Chequer et al. 2006, Kobayashi \& Karino 2016).

Veterinarians practicing with horses need to perfect themselves to understand the differences between them and mules. GSH in female horses and mules is still incipient, particularly in the analysis of vessel walls. This study aimed to evaluate and compare the echogenicity and echotexture of the walls of the common carotid arteries of healthy female horses and mules using the GSH technique and correlate them with age, body mass, and vessel diameters. It also sought to assess the echogenicity and echotexture of carotid artery walls between mule genders.

\section{MATERIALS AND METHODS}

This study was approved by the Ethics Committee on Animals Use (CEUA) of the School of Veterinary Medicine and Animal Science, São Paulo State University (FMVZ/Unesp) under protocol no. 0100/2017. The research was conducted at the Edgárdia farm, Botucatu campus of the FMVZ/Unesp.

Twenty-two animals belonging to the equine teaching, research, and extension area of the FMVZ/Unesp, Botucatu campus, were used in this survey. The animals were classified into two groups: 11 healthy, cross-bred, female horses with $348-486 \mathrm{~kg}$ body mass, aged 5-25 years; 11 healthy mules (six males and five females) with $350-462 \mathrm{~kg}$ body mass, aged 4-12 years. The mules were also divided according to gender into males and females.

For ultrasound (US) examination, the animals were driven to individual squeeze chutes by a trained guide, and their positioning was respected according to accommodation, where they all remain with the head above the line of the withers. The animals did not fast for either feed or water, and were contained manually by trained professionals during the procedures.

Prior to the US examination, isopropyl alcohol was applied at a concentration of $30 \%$ water and $70 \%$ alcohol in the region to be examined, and silicone gel was used to protect the equipment transducers. The use of alcohol eliminates the need for trichotomy, and along with the gel improves conduction of the ultrasound waves. US examination was performed using a MyLab ${ }^{\circledR} 30$ (Esaote; Italy) and linear transducers (3.0-11.0 MHz) (Esaote; Italy) to obtain B-mode 
images of the female horses and mules, classifying the carotid arteries in three different regions: cranial, middle, and caudal (Fig.1).

These anatomical regions of interest (ROI) were classified as a cranial, middle and caudal measurement points. The cranial measurement point was identified as a line tangential to the condyles of the occipital bone, dorsally, and the angle of the mandible, ventrally. The middle measurement point was considered as a dorsoventral line, caudally, tangential to the articular fovea of the fourth cervical vertebra. The caudal measurement point was established as a dorsoventral line, caudally, tangential to the seventh cervical vertebra.

Owing to the difference in size and body mass between the animals, the image techniques (gain of brightness and depth) were different aiming to maximize the quality of the images in each case. After the procedures, the US images of all animals were assessed using specific software (Image $₫ \circledR$ - National Institutes of Health), in which the grayscale histogram (GSH) tool was applied to all images in the longitudinal plane of the right and left common carotid arteries.

For the GSH measurements, it was decided to perform the measurements on the upper wall of the vessel in the three regions (cranial, middle, and caudal) to avoid a possible acoustic reinforcement artifact. A range of 770-1000 pixels was considered for sample collection within the ROI, and values of the following image variables were obtained: Count, Mean, Max, Min, SD, Mode, and Mode(Count) (Fig.2), and subsequently inserted into a Microsoft Excel 2013 spreadsheet for statistical analysis. Echotexture was obtained according to the equation Mode(Count)/Count, and the result was then multiplied by 100 to convert the values in percentage (\%). Results are more and less homogeneous as they are closer to $100 \%$ and $0 \%$, respectively.

Statistical analysis was conducted using the SAS System 9.0 for the calculation of the mean, median, and standard deviation in each group, and the Mann-Whitney test was subsequently applied for the comparison between female horses and mules and between mule genders. Sperman's correlation was also used for comparison between the GSH variables and the factors age, body mass, and longitudinal diameter and longitudinal wall of the vessel. A significance level of $5 \%(p \leq 0.05)$ was adopted for all statistical analyses.

\section{RESULTS}

No statistically significant difference was observed between female horses and mules with respect to the variable Count $(P=0.0391)$ on the right caudal side region, with female horses showing higher values compared with those of mules (Table 1), which means that pixel quantification was higher in this region than in the other regions.

Statistically significant difference was found between the variable Mean on the middle right side $(P=0.0270)$, middle left side $(P=0.0366)$, and caudal left side $(P=0.0090)$, with quantification of pixels higher in mules than in female horses. This indicates that the female horses obtained means of gray-levels different from those of the mules in the previously mentioned regions, that is, more hypoechogenic. Statistically significant difference was observed for the variable Min on the middle right side $(P=0.0219)$, with the mules showing higher values, that is, the female horses showed more hypoechogenic pixel quantification than the mules in this ROI. Statistically significant difference was found for the variables Max and Mode on the middle left side $(P=0.093$ for Max and $P=0.00310$ for Mode) and the caudal left side $(P=0.0140$ for Max and $P=0.0350$ for Mode), with the mules showing higher values than those of the female horses, which means that mules present greater echogenicity than female horses in these ROIs.

Joint analysis of the means of the variable Mean showed that the mules had greater echogenicity in all regions and sides evaluated compared with those of the female horses. Echotexture, obtained by the Mode(Count)/Count(\%) ratio,
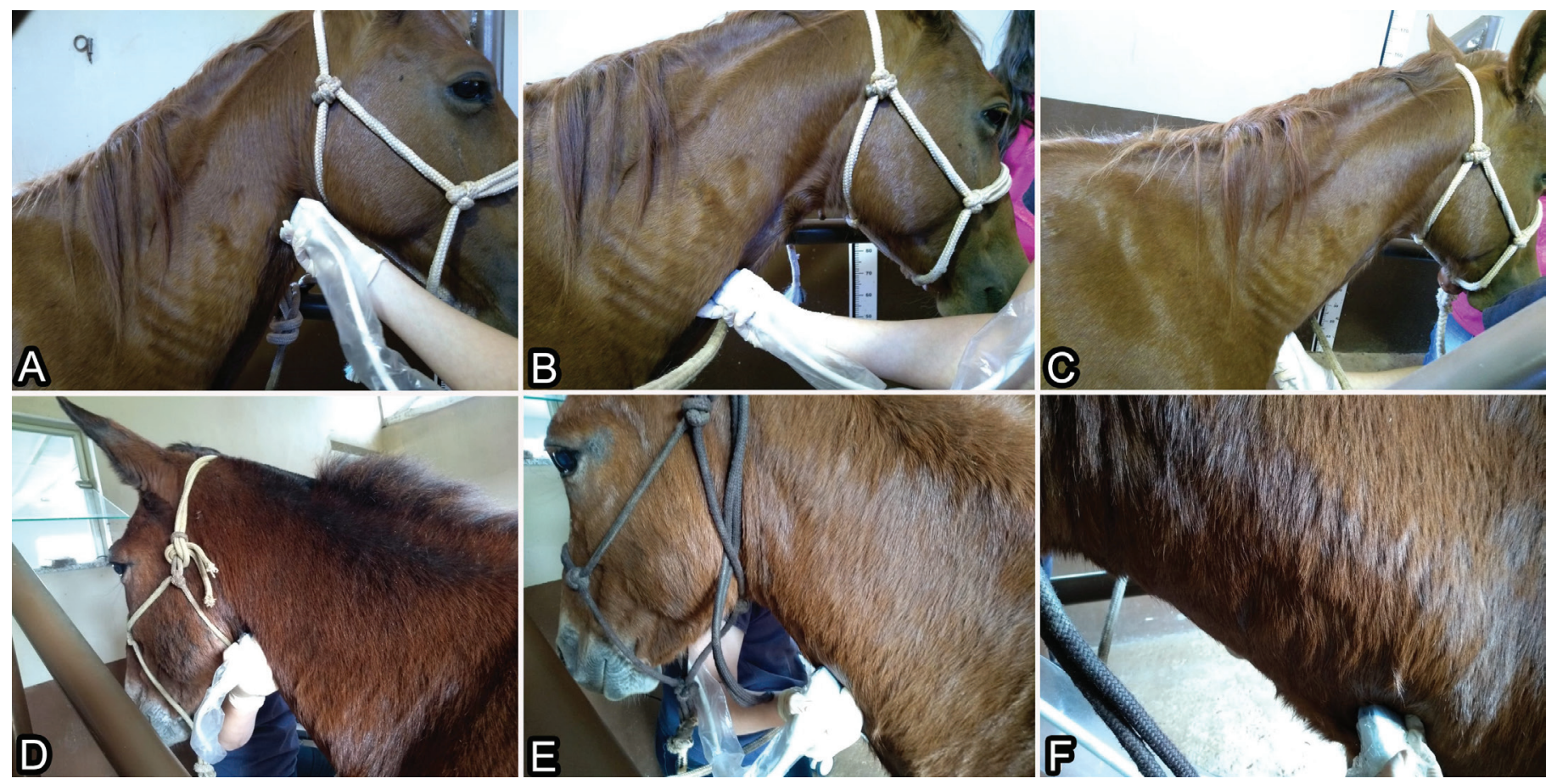

Fig.1. Longitudinal plane of the following three regions of the common carotid arteries of female horses: (A) cranial, (B) middle and (C) caudal; and of mules: (D) cranial, (E) middle and (F) caudal. 


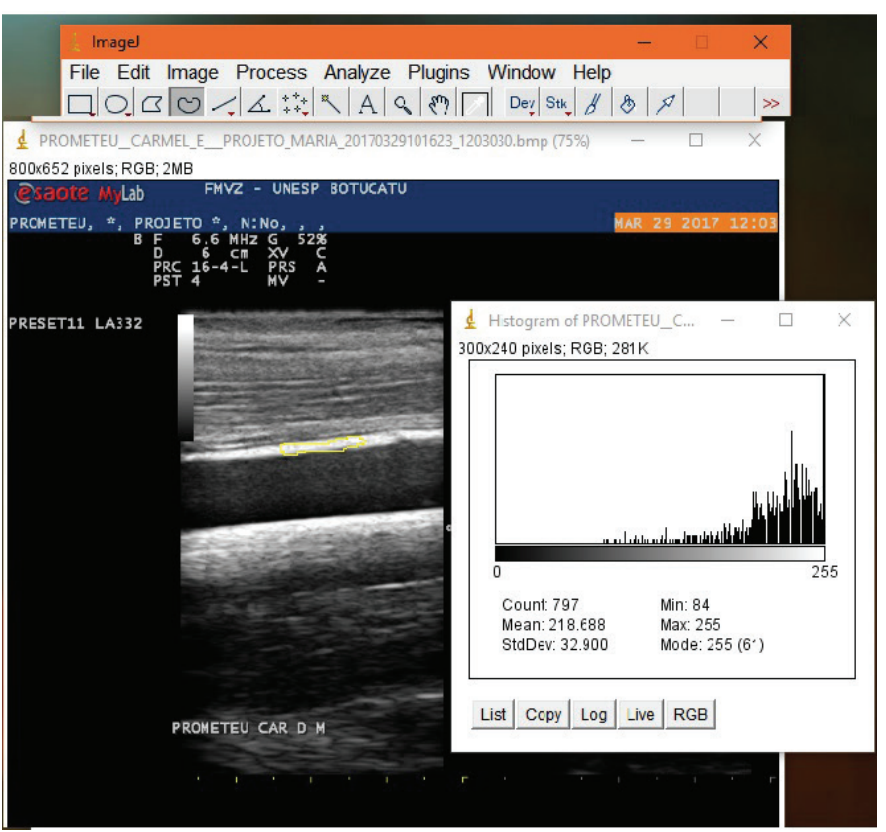

Fig.2. Ultrasound image of the left carotid artery in the cranial region of a female horse in which the following can be observed: the total of selected pixels (Count), which ranged from 770 to 1000 in each image in this study; the mean gray-level (Mean) of the selected pixels and the standard deviation (SD), where zero (0) represents a totally black (hypoechoic/hypoechogenic) pixel and 255 represents a totally white (hyperechoic/hyperechogenic) pixel; the most hyperechogenic (Max) and most hyporeogenic (Min) values observed in the sample; the mode (Mode), which represents the most frequent gray-level of the sample and, in parenthesis, the equivalent mode of pixel gray-levels [Mode(Count)].

showed heterogenic pixel quantification, as the percentages obtained were low (3-8\%) in female horses and mules, although without statistically significant difference.

As for mule gender, only the variable Mode showed statistically significant difference on the cranial right side $(P=0.0477)$, with females presenting higher pixel quantification (hyperechogenic) compared with that of males. Echotexture showed heterogenic pixel quantification, because the percentages obtained were low (2-13\%) between genders, although without statistically significant difference.

Regarding the mules (Table 2), positive correlation was found between the variable Mean and the variables Min $(P<0.001)$, Max $(P<0.001)$, Mode $(P<0.001)$, Mode(Count) $(P<0.001)$, and Mode(Count)/Count $(\%)(P<0.001)$.

The variable SD showed positive correlation with the variable Max $(P=0.0003)$ and negative correlation with the variable Min $(P<0.001)$. The variable Min showed positive correlation with the variables Mode $(P=0.0418)$, Mode(Count) $(P=0.0002)$, Mode(Count)/Count $(\%)(P=0.0002)$, and Mean $(P<0.001)$, and negative correlation with the variable SD $(P<0.001)$.

For the variable Max, positive correlation was identified with the variables Mode $(P<0.001)$, Mode(Count) $(P=0.0160)$, Mode(Count)/Count $(\%)(P=0.0349)$, Mean $(P<0.001)$, and SD $(P=0.0003)$. The variable Mode presented positive correlation with the variables Mode(Count) $(P<0.001)$,
Mode(Count)/Count $(\%)(P<0.001)$, Mean $(P<0.001)$, Max $(P<0.001)$, and $\operatorname{Min}(P=0.0418)$.

With respect to the variable Mode(Count), positive correlation was verified with the variables Mode $(P<0.001)$, Mode(Count)/Count $(\%)(P<0.001)$, Mean $(P<0.001)$, $\operatorname{Max}(P=0.0160)$, and Min $(P=0.0002)$. The variable Mode(Count)/Count(\%) showed positive correlation with the variables Mode $(P<0.001)$, Mode(Count) $(P<0.001)$, Mean $(P<0.001)$, Min $(P=0.0002)$, and Max $(P=0.0349)$.

As for the age factor, negative correlation was observed with the variables Mode $(P=0.0004)$, Mode(Count) $(P=0.0047)$, Mode(Count)/Count $(\%)(P=0.0034)$, and Mean $(P=0.0011)$. The body mass factor negatively correlated with the variables Mean $(P=0.0045)$, Max $(P=0.0253)$, and Mode $(P=0.0135)$. The factor longitudinal wall showed positive correlation with the variable $\operatorname{Max}(P=0.0072)$.

Regarding the female horses (Table 3), the variable Mean presented positive correlation with the variables Mode $(P<0.001)$, Mode(Count) $(P<0.001)$, Mode(Count)/Count $(\%)$ $(P<0.001)$, Max $(P<0.001)$, and Min $(P<0.001)$.

The variable SD showed positive correlation with the variable $\operatorname{Max}(P=0.0011)$ and negative correlation with the variables Min $(P<0.001)$, Count $(P=0.0392)$, Mode(Count) $(P=0.0140)$, and Mode(Count)/Count(\%) $(P=0.0152)$. As for the variable Min, positive correlation was found with the variables Count $(P=0.0267)$, Mean $(P<0.001)$, Mode $(P<0.001)$, Mode(Count) $(P=0.0038)$, Mode(Count)/Count $(\%)(P=0.0065)$, and Max $(P=0.0181)$ and negative correlation was observed with the variable SD $(P<0.001)$.

With regards to the variable Max, positive correlation was evidenced with the variables Min $(P=0.0181)$, Mean $(P<0.001)$, Mode $(P<0.001)$, and SD $(P=0.0011)$. The variable Mode showed positive correlation with the variables Mean $(P<0.001)$, Max $(P<0.001)$, Min $(P<0.001)$, Mode(Count) $(P<0.001)$, and Mode(Count)/Count $(\%)(P<0.001)$.

The variable Mode(Count) presented positive correlation with the variables Mode $(P<0.001)$, Mode(Count)/Count $(\%)$ $(P<0.001)$, Mean $(P<0.001)$, and Min $(P=0.0038)$, and negative correlation with the variable SD $(P=0.0140)$. As for the variable Mode (Count)/Count(\%), positive correlation was found with the variables Mode $(P<0.001)$, Mode(Count) $(P<0.001)$, Mean $(P<0.001)$, Min $(P=0.0065)$ and negative correlation was observed with the variable SD $(P=0.0152)$. The body mass factor showed positive correlation with the variables Mean $(P=0.0161)$ and Mode $(P=0.0105)$.

\section{DISCUSSION}

In human medicine, ultrasound (US) examination has been widely used to estimate of the degree of stenosis and assess the echogenicity of atherosclerotic plaques deposited in the common carotid arteries (Sumner 1990). Physicians have relied on the echogenicity and echotexture of vessel walls to determine the soft tissue content and the amount of calcification deposited (Baroncini et al. 2006).

The US images obtained in this study sought to maintain better quality, necessitating a change in technique (gain of brightness and depth) in each case. According to Sarmento et al. (2014), this technique, even when altered, does not significantly interfere with grayscale histogram (GSH) results. According to Lima et al. (2013), the acoustic reinforcement artifact represents a certain localized increase in echo amplitude 
Table 1. Mean, median and standard deviation of the variables of interest: Count, Mean, SD, Min, Max, Mode, Mode (Count), and Mode (Count)/Count (\%) referring to the GSH, followed by the $p$-value of the Mann-Whitney test for the comparison between female horses and mules

\begin{tabular}{|c|c|c|c|c|c|c|c|c|c|}
\hline \multirow{2}{*}{ Side } & \multirow{2}{*}{ Region } & \multirow{2}{*}{ Variables } & \multicolumn{3}{|c|}{ Female horses } & \multicolumn{3}{|c|}{ Mules } & \multirow{2}{*}{$p$-value } \\
\hline & & & Mean & Median & SD & Mean & Median & SD & \\
\hline \multirow[t]{18}{*}{ Right } & Cranial & Count & 852 & 866 & 59 & 875 & 882 & 67 & 0.5110 \\
\hline & & Mean & 156 & 153 & 63 & 184 & 192 & 31 & 0.2880 \\
\hline & & Min & 39 & 22 & 47 & 68 & 82 & 47 & 0.1367 \\
\hline & & Max & 212 & 239 & 54 & 248 & 255 & 15 & 0.1738 \\
\hline & & Mode (Count)/Count (\%) & 8 & 4 & 10 & 8 & 6 & 9 & 0.8620 \\
\hline & Middle & Count & 880 & 877 & 61 & 863 & 837 & 63 & 0.5850 \\
\hline & & Mean & 142 & 147 & 64 & 201 & 208 & 24 & $0.0270^{*}$ \\
\hline & & SD & 45 & 50 & 11 & 35 & 35 & 13 & 0.1046 \\
\hline & & Min & 40 & 31 & 41 & 93 & 82 & 35 & $0.0219^{*}$ \\
\hline & & Mode (Count)/Count (\%) & 5 & 2 & 5 & 5 & 3 & 4 & 0.2670 \\
\hline & Caudal & Count & 916 & 954 & 71 & 850 & 848 & 56 & $0.0391^{*}$ \\
\hline & & Mean & 156 & 153 & 34 & 173 & 175 & 24 & 0.1156 \\
\hline & & SD & 26 & 26 & 10 & 28 & 25 & 13 & 0.8457 \\
\hline & & Min & 76 & 80 & 34 & 93 & 90 & 29 & 0.1298 \\
\hline & & Max & 214 & 215 & 33 & 226 & 224 & 23 & 0.3999 \\
\hline & & Mode & 162 & 160 & 43 & 190 & 185 & 43 & 0.0959 \\
\hline & & Mode (Count) & 29 & 29 & 12 & 50 & 25 & 64 & 0.4775 \\
\hline & & Mode (Count)/Count (\%) & 3 & 3 & 1 & 6 & 3 & 7 & 0.4029 \\
\hline \multirow[t]{17}{*}{ Left } & Cranial & Count & 875 & 880 & 51 & 930 & 944 & 59 & 0.0625 \\
\hline & & Mean & 153 & 150 & 55 & 173 & 192 & 53 & 0.3892 \\
\hline & & Mean & 145 & 143 & 50 & 191 & 190 & 39 & $0.0366^{*}$ \\
\hline & & SD & 41 & 28 & 36 & 40 & 41 & 13 & 0.3358 \\
\hline & & Min & 62 & 59 & 49 & 70 & 62 & 43 & 0.5394 \\
\hline & & Max & 215 & 219 & 36 & 252 & 255 & 70 & $0.0093^{*}$ \\
\hline & & Mode & 150 & 151 & 62 & 216 & 222 & 53 & $0.0310^{*}$ \\
\hline & & Mode (Count) & 25 & 23 & 5 & 55 & 20 & 50 & 1.0000 \\
\hline & & Mode (Count)/Count (\%) & 3 & 3 & 1 & 6 & 3 & 5 & 0.8968 \\
\hline & Caudal & Count & 929 & 955 & 64 & 891 & 892 & 53 & 0.1704 \\
\hline & & Mean & 148 & 144 & 25 & 184 & 193 & 28 & $0.0090^{*}$ \\
\hline & & SD & 28 & 27 & 9 & 31 & 33 & 11 & 0.3817 \\
\hline & & Min & 69 & 65 & 25 & 96 & 88 & 39 & 0.0543 \\
\hline & & Max & 208 & 204 & 25 & 242 & 252 & 22 & $0.0140^{*}$ \\
\hline & & Mode & 158 & 142 & 46 & 200 & 206 & 31 & $0.0350^{*}$ \\
\hline & & Mode (Count) & 27 & 26 & 5 & 25 & 22 & 10 & 0.1160 \\
\hline & & Mode (Count)/Count (\%) & 3 & 3 & 1 & 3 & 2 & 1 & 0.3817 \\
\hline
\end{tabular}

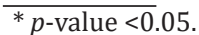


Table 2. Sperman's correlation between the GSH variables: Count, Mean, SD, Min, Max, Mode, Mode (Count), Mode (Count)/Count (\%) and the factors age, body mass, and longitudinal diameter and longitudinal wall of the vessels of mules

\begin{tabular}{|c|c|c|c|c|c|c|c|c|}
\hline & Count & Mean & SD & Min & Max & Mode & $\begin{array}{l}\text { Mode } \\
\text { (Count) }\end{array}$ & Mode(Count)/Count (\%) \\
\hline \multirow[t]{2}{*}{ Count } & 1.00 & 0.14 & 0.11 & -0.11 & 0.19 & 0.10 & 0.23 & 0.10 \\
\hline & - & 0.2725 & 0.3832 & 0.3985 & 0.1216 & 0.4091 & 0.0658 & 0.4276 \\
\hline \multirow[t]{2}{*}{ Mean } & 0.14 & 1.00 & -0.21 & 0.62 & 0.59 & 0.80 & 0.66 & 0.64 \\
\hline & 0.2725 & - & 0.0841 & $<0.001^{*}$ & $<0.001^{*}$ & $<0.001^{*}$ & $<0.001^{*}$ & $<0.001^{*}$ \\
\hline \multirow[t]{2}{*}{ SD } & 0.11 & -0.21 & 1.00 & -0.78 & 0.43 & 0.23 & -0.21 & -0.22 \\
\hline & 0.3832 & 0.0841 & - & $<0.001^{*}$ & $0.0003^{*}$ & 0.0575 & 0.0859 & 0.0822 \\
\hline \multirow[t]{2}{*}{ Min } & -0.11 & 0.62 & -0.78 & 1.00 & -0.01 & 0.25 & 0.44 & 0.44 \\
\hline & 0.3985 & $<0.001^{*}$ & $<.0001^{*}$ & - & 0.9426 & $0.0418^{*}$ & $0.0002^{*}$ & $0.0002^{*}$ \\
\hline \multirow[t]{2}{*}{$\operatorname{Max}$} & 0.19 & 0.59 & 0.43 & -0.01 & 1.00 & 0.71 & 0.30 & 0.26 \\
\hline & 0.1216 & $<0.001^{*}$ & $0.0003^{*}$ & 0.9426 & - & $<.0001^{*}$ & $0.0160^{*}$ & $0.0349^{*}$ \\
\hline \multirow[t]{2}{*}{ Mode } & 0.10 & 0.80 & 0.23 & 0.25 & 0.71 & 1.00 & 0.69 & 0.69 \\
\hline & 0.4091 & $<0.001^{*}$ & 0.0575 & $0.0418^{*}$ & $<0.001^{*}$ & - & $<0.001^{*}$ & $<0.001^{*}$ \\
\hline \multirow[t]{2}{*}{ Mode (Count) } & 0.23 & 0.66 & -0.21 & 0.44 & 0.30 & 0.69 & 1.00 & 0.98 \\
\hline & 0.0658 & $<0.001^{*}$ & 0.0859 & $0.0002^{*}$ & $0.0160^{*}$ & $<0.001^{*}$ & - & $<0.001^{*}$ \\
\hline \multirow[t]{3}{*}{ Mode(Count)/Count (\%) } & 0.10 & 0.64 & -0.22 & 0.44 & 0.26 & 0.69 & 0.98 & 1.00 \\
\hline & 0.4276 & $<0.001^{*}$ & 0.0822 & $0.0002^{*}$ & $0.0349^{*}$ & $<0.001^{*}$ & $<0.001^{*}$ & - \\
\hline & Count & Mean & SD & Min & Max & Mode & $\begin{array}{c}\text { Mode } \\
\text { (Count) }\end{array}$ & Mode(Count)/Count (\%) \\
\hline \multirow[t]{2}{*}{ Age } & -0.05 & -0.41 & -0.09 & -0.17 & -0.11 & -0.44 & -0.36 & -0.37 \\
\hline & 0.7302 & $0.0011^{*}$ & 0.4728 & 0.1839 & 0.3873 & $0.0004^{*}$ & $0.0047^{*}$ & $0.0034^{*}$ \\
\hline \multirow[t]{2}{*}{ Body mass } & 0.00 & -0.36 & -0.03 & -0.15 & -0.29 & -0.32 & -0.11 & -0.12 \\
\hline & 0.9698 & $0.0045^{*}$ & 0.8140 & 0.2411 & $0.0253^{*}$ & $0.0135^{*}$ & 0.4037 & 0.3609 \\
\hline \multirow[t]{2}{*}{ Longitudinal diameter } & 0.04 & -0.08 & -0.23 & 0.08 & 0.01 & -0.26 & -0.13 & -0.14 \\
\hline & 0.7943 & 0.5678 & 0.0896 & 0.5359 & 0.9264 & 0.0551 & 0.3388 & 0.2869 \\
\hline \multirow[t]{2}{*}{ Longitudinal wall } & -0.04 & 0.12 & 0.24 & -0.07 & 0.36 & 0.20 & -0.09 & -0.09 \\
\hline & 0.7741 & 0.3876 & 0.0690 & 0.6290 & $0.0072^{*}$ & 0.1415 & 0.5141 & 0.5009 \\
\hline
\end{tabular}

${ }^{*} p$-value $<0.05$.

that occurs subsequently to a low-attenuation structure such as liquid. In US examination, the reinforcement appears as an area of more intense clarity. In this study, measurements were performed in the upper vessel wall to avoid possible artifact. However, in most studies using GSH to address common carotid arteries in humans (Wohlin et al. 2009, Noto et al. 2012, Sarmento et al. 2014), measurements are performed in the lower (distal) wall because of the presence of atherosclerotic plaques, but it is not possible to affirm whether the reinforcement artifact significantly interferes (positively or negatively) with the GSH results.

Most GSH studies conducted with humans (Lind et al. 2008, Anderson et al. 2009, Noto et al. 2012, Sarmento et al. 2014) focus only on the evaluation of atherosclerotic plaques, and studies addressing the vessel walls of healthy patients have not been found in the surveyed literature, which shows the need for further research on this theme.

No changes were visualized in the vessels analyzed, which shows the need for a more detailed GSH study in cases of atherosclerotic plaques, considering that these alterations have become quite frequent in companion animals (Hess et al. 2003). According to Ribeiro \& Shintaku (2004), the emergence of atherosclerotic plaques in humans is associated with poor nutrition. It can be assumed that the emergence of atherosclerotic plaques in animals is linked to their humanization.

Aguiar et al. (2014) described a case of atherosclerotic plaques in the common carotid artery of a 32-year-old horse with a history of heart disease, and observed an echotic mass obstructing $40 \%$ of the vessel lumen and impairing blood flow. In these situations, as well as in human medicine (Baroncini et al. 2006, Wohlin et al. 2009, Noto et al. 2012, Sarmento et al. 2014), GSH can quantitatively complement the evaluation, thus enabling spatial differentiation of distribution in gray-levels in an image or texture.

Only healthy animals were used in the present study, and according to the GSH, the vessel walls showed heterogeneous echotexture both in the mules and female horses, but without statistically significant difference between them. Regarding echogenicity, the mules showed more hyperechogenic vessel walls, which may be associated with the fact that they are anatomically and physiologically different from horses (Burnhan 2002, Alsafy et al. 2008, Smith 2009).

Results of the GSH showed statistically significant difference between mule genders only for the variable Mode on the cranial right side, with females presenting more hyperechogenic vessel walls compared with those of males. No difference between genders was observed with regard to echotexture. 
Table 3. Sperman's correlation between the GSH variables: Count, Mean, SD, Min, Max, Mode, Mode (Count), Mode (Count)/Count (\%) and the factors age, body mass, and longitudinal diameter and longitudinal wall of the vessels of female horses

\begin{tabular}{|c|c|c|c|c|c|c|c|c|}
\hline & Count & Mean & SD & Min & Max & Mode & $\begin{array}{c}\text { Mode } \\
\text { (Count) }\end{array}$ & Mode(Count)/Count (\%) \\
\hline \multirow[t]{2}{*}{ Count } & 1.00 & 0.09 & -0.25 & 0.27 & 0.03 & 0.06 & 0.22 & 0.04 \\
\hline & - & 0.4786 & $0.0392^{*}$ & $0.0267 *$ & 0.8287 & 0.6210 & 0.0705 & 0.7384 \\
\hline \multirow[t]{2}{*}{ Mean } & 0.09 & 1.00 & -0.03 & 0.64 & 0.82 & 0.94 & 0.47 & 0.46 \\
\hline & 0.4786 & - & 0.7930 & $<.0001^{*}$ & $<0.001^{*}$ & $<0.001^{*}$ & $<0.001^{*}$ & $<0.001^{*}$ \\
\hline \multirow[t]{2}{*}{ SD } & -0.25 & -0.03 & 1.00 & -0.63 & 0.39 & 0.14 & -0.30 & -0.30 \\
\hline & $0.0392^{*}$ & 0.7930 & - & $<0.001^{*}$ & 0.0011* & 0.2617 & $0.0140^{*}$ & $0.0152^{*}$ \\
\hline \multirow[t]{2}{*}{ Min } & 0.27 & 0.64 & -0.63 & 1.00 & 0.29 & 0.47 & 0.35 & 0.33 \\
\hline & $0.0267^{*}$ & $<0.001^{*}$ & $<0.001^{*}$ & - & $0.0181 *$ & $<0.001^{*}$ & $0.0038^{*}$ & $0.0065^{*}$ \\
\hline \multirow[t]{2}{*}{ Max } & 0.03 & 0.82 & 0.39 & 0.29 & 1.00 & 0.83 & 0.21 & 0.21 \\
\hline & 0.8287 & $<0.001^{*}$ & $0.0011^{*}$ & $0.0181^{*}$ & _- & $<0.001^{*}$ & 0.0834 & 0.0905 \\
\hline \multirow[t]{2}{*}{ Mode } & 0.06 & 0.94 & 0.14 & 0.47 & 0.83 & 1.00 & 0.49 & 0.49 \\
\hline & 0.6210 & $<0.001^{*}$ & 0.2617 & $<0.001^{*}$ & $<0.001^{*}$ & _- & $<0.001^{*}$ & $<0.001^{*}$ \\
\hline \multirow[t]{2}{*}{ Mode (Count) } & 0.22 & 0.47 & -0.30 & 0.35 & 0.21 & 0.49 & 1.00 & 0.97 \\
\hline & 0.0705 & $<0.001^{*}$ & $0.0140^{*}$ & $0.0038^{*}$ & 0.0834 & $<0.001^{*}$ & _- & $<0.001^{*}$ \\
\hline \multirow[t]{3}{*}{ Mode(Count)/Count (\%) } & 0.04 & 0.46 & -0.30 & 0.33 & 0.21 & 0.49 & 0.97 & 1.00 \\
\hline & 0.7384 & $<0.001^{*}$ & $0.0152^{*}$ & $0.0065^{*}$ & 0.0905 & $<0.001^{*}$ & $<0.001^{*}$ & - \\
\hline & Count & Mean & SD & Min & Max & Mode & $\begin{array}{c}\text { Mode } \\
\text { (Count) }\end{array}$ & Mode (Count)/Count (\%) \\
\hline \multirow[t]{2}{*}{ Age } & -0.02 & -0.13 & -0.03 & 0.01 & -0.02 & -0.16 & -0.12 & -0.10 \\
\hline & 0.8972 & 0.3125 & 0.7868 & 0.9145 & 0.8442 & 0.2126 & 0.3245 & 0.4121 \\
\hline \multirow[t]{2}{*}{ Body mass } & -0.05 & 0.30 & 0.14 & 0.05 & 0.22 & 0.31 & 0.14 & 0.14 \\
\hline & 0.6690 & $0.0161 *$ & 0.2491 & 0.6733 & 0.0774 & $0.0105^{*}$ & 0.2595 & 0.2533 \\
\hline \multirow[t]{2}{*}{ Longitudinal diameter } & 0.06 & 0.01 & 0.02 & 0.02 & -0.05 & -0.04 & -0.15 & -0.16 \\
\hline & 0.6812 & 0.9446 & 0.8640 & 0.9076 & 0.7026 & 0.7718 & 0.2826 & 0.2462 \\
\hline \multirow[t]{2}{*}{ Longitudinal wall } & 0.01 & 0.17 & -0.19 & 0.24 & 0.09 & 0.09 & -0.02 & 0.02 \\
\hline & 0.9664 & 0.2255 & 0.1727 & 0.0807 & 0.5378 & 0.5352 & 0.9016 & 0.8894 \\
\hline
\end{tabular}

$\bar{*}$-value $<0.05$.

A for the mules, positive correlation was observed between the longitudinal wall factor and the variable Max, which indicates that the larger the longitudinal wall, the greater the possibility of hyperechogenic pixels; this information was not significant for female horses. In mules, negative correlation was found between the body mass factor and the variables Mean, Max, and Mode. This means that the lower the body mass of the animals, the greater the possibility of hyperechogenic pixels, which differentiates the horses, because the body mass factor showed positive correlation with the variables Mean and Mode, that is, the higher the body mass, the greater the possibility of hyperechogenic pixels.

The positive correlation between the variables Mean and Mode is quite normal, and this similarity has been described in many studies involving GSH (Santos et al. 2009, Svicero 2014), corroborating the findings of the present study, in which this similarity was observed both in the mules and female horses. It is worth highlighting that the variables Mean and Mode can be statistically different (Santos 2017), which may hinder interpretation of the GSH results.

Regarding the echotexture of the mules, it was identified that the younger the animal, the greater the homogeneity of the vessel wall; however, this affirmation was not relevant for female horses. According to Bersi et al. (2014) and Kiyota (2014), stiffening of the common carotid arteries is associated with aging. Stiffening, as well as calcification of the arteries, cause the vessel walls to present a hyperechogenic appearance on US examination, accompanied by acoustic shadow due to high acoustic impedance, which may also be associated with aging (Park et al. 1993, Saijo et al. 2006a, 2006b, Shaw et al. 2006, Kiyota 2014, Soares et al. 2015). However, in this study, the age factor in the mules had negative correlation with the variables Mode and Mode(Count)/Count(\%).This means that, as the animal ages the vessel walls exhibit greater quantification of hypoechogenic pixels; this affirmation was not significant for female horses.

Due to the lack of studies in the literature addressing GSH in the vessel walls of mules and female horses, it is not possible to state whether this difference in echogenicity and echotexture occurs between these animals, which highlights the importance of further studies on GSH.

\section{CONCLUSIONS}

Echogenicity of the longitudinal walls of the common carotid arteries differed between female horses and mules.

Echotexture was heterogeneous and statistically similar among the animals. 
Age and body mass inversely influenced the echogenicity of mules

The age factor did not influence the GSH variables in the equine females, whereas the body mass factor positively influenced only the echogenicity.

Conflict of interest statement.- The authors have no competing interests.

\section{REFERENCES}

Aguiar A., Dantas A., Viana G.F. \& Machado V.M.V. 2014. Ateroma em artéria carótida comum de equino detectado através de exame ultrassonográfico: relato de caso. Anais IV Simpósio International de Diagnóstico por Imagem Veterinário, Belo Horizonte, MG, p.1-3. (Resumo)

Alsafy M.A.M., El-Kammar M.H. \& El-Gendy S.A.A. 2008. Topographical anatomy, computed tomography and surgical approach of the guttural pouches of the donkey. J. Equine Vet. Sci. 28(4):215-222. <http://dx.doi. org/10.1016/j.jevs.2008.02.005>

Anderson J., Sundström J., Gustavsson T., Hulthe J., Elmgren A., Zilmer K., Zilmer M. \& Lind L. 2009. Echogenecity of the carotid intima-media complex is related to cardiovascular risk factors, dyslipidemia, oxidative stress and inflammation: the Prospective Investigation of the Vasculature in Uppsala Seniors (PIVUS) study. Atherosclerosis 204(2):612-618. <http://dx.doi. org/10.1016/j.atherosclerosis.2008.10.038> <PMid:19200993>

Armstrong V., Hansen W.F., Voorhis B.J.V. \& Syrop C.H. 2003. Detection of cesarean scars by transvaginal ultrasound. Obstetr. Gynecol. 101(1):6165. <PMid:12517646>

Baroncini L.A.V., Pazin Filho A., Junior L.O.M., Martins A.R., Ramos S.G., Cherri J. \& Piccinato C.E. 2006. Caracterização tecidual ultra-sônica da placa carotídea vulnerável pela análise vídeodensitométrica. Revta Bras. Ecocardiografia 19(1):37-44.

Bersi M.R., Ferruzzi J., Eberth J.F., Gleason-Junior R.L. \& Humphrey J.D. 2014 Consistent biomechanical phenotyping of common carotid arteries from seven genetic, pharmacological, and surgical mouse models. Anim. Biomed. Eng. 42(6):1207-1223. <http://dx.doi.org/10.1007/s10439-014-0988-6> $<$ PMid:24590490>

Burnhan S.L. 2002. Anatomical differences of the donkey and mule. AAEP Proceed. 48(1):102-109.

Chequer G., Nascimento B.R., Navarro T.P., Falqueto E.B., Alencar M.C., Miranda M.C., Mandil A., Saad J.A., Fonseca C. \& Ribeiro A.L. 2006. Espessamento médio-intimal da carótida e função endotelial na doença arterial coronariana. Arq. Bras. Cardiol. 87(2):84-90. <http://dx.doi.org/10.1590/S0066782X2006001500004> <PMid:16951824>

Dantas A., Vettorato M.C., Oba E., Machado V.M.V.\& Charlier M.G.S. 2016. Uso da técnica de histograma em escala de cinza para avaliação do desenvolvimento mamário de animais leiteiros.V Jornada Científica e Tecnológica da Faculdade de Tecnologia de Botucatu, Botucatu, SP. 6p. (Resumo)

Hess R.S., Kass P.H. \& Winkle T.J. 2003. Association between diabetes mellitus, hypothyroidism or hyperadrenocorticiosm, and atherosclerosis in dogs. J. Vet. Intern. Med. 17(4):489-494. <http://dx.doi.org/10.1111/j.1939-1676.2003. tb02469.x><PMid:12892299>

Kiyota T.A. 2014. Idade pulmonar está relacionada a alterações estruturais carotídeas em indivíduos hipertensos. Master's Thesis, Faculdade de Ciências Médicas, Universidade Estadual de Campinas, Campinas, SP. 61p.

Kobayashi N. \& Karino T. 2016. Flow behavior and distribution of embolusmodel particles at the terminal bifurcation of the human internal cartotid artery. World Neurosurg. 90(1):469-477. <http://dx.doi.org/10.1016/j. wneu.2016.03.012><PMid:26987631>

Lee C.H., Choi J.W., Kim K.A., Seo T.S., Lee J.M. \& Park C.M. 2006. Usefulness of standard deviation on the histogram of ultrasound as a quantitative value for hepatic parenchymal echo texture preliminary study. Ultrasound Med. Biol. 32(12):1817-1826. <http://dx.doi.org/10.1016/j.ultrasmedbio.2006.06.014>
Lee J.J. 2010. Formação e processamento de imagens de ultrassom. Master's Thesis, Escola de Engenharia de São Carlos, Universidade de São Paulo, São Carlos, SP. 65p. <http://dx.doi.org/10.11606/D.18.2010.tde-24062010$154946>$.

Lima J.L., André A. \& Santos A.C. 2013. Reprodução e estudo de artefatos no ultrassom. Revta Bras. Física Med. 7(3):205-208.

Lind L., Andersson J., Rönn M., Gustavsson T., Holdfelt P., Hulthe J., Elmgren A., Zilmer K. \& Zilmer M. 2008. Brachial artery intima-media thickness and echogenicity in relation to lipids and markers of oxidative stress in elderly subjects: the prospective investigation of the vasculature in Uppsala Seniors (PIVUS). Study Lipids 43(2):133-141. <http://dx.doi.org/10.1007/ s11745-007-3125-6><PMid:18004605>

Maeda K., Utsu M. \& Kihaile P.E. 1998. Quantification of ultrasonographic echogenicity with grey-level histogram width: a clinical tissue characterization. Ultrasound Med. Biol. 24(2):225-234.

Mendonça J.A. 2017. 0 histograma de imagens coloridas permite melhor visualização de danos ecotexturais pelo ultrassom. Bras. Reumatol. 57(1):88-91. <http://dx.doi.org/10.1016/j.rbr.2014.12.016>

Noto N., Okada T., Abe Y., Miyashita M., Kanamaru H., Karasawa K., Ayusawa M., Sumitomo N. \& Mugishima H. 2012. Characteristics of earlier atherosclerotic involvement in adolescent patients with Kawasaki disease and coronary artery lesions: significance of gray scale median on B-mode ultrasound. Atherosclerosis 222(1):106-109. <http://dx.doi.org/10.1016/j. atherosclerosis.2012.01.049><PMid:22377394>

Park J.C., Siegel R.J. \& Demer L.L. 1993. Effect of calcification and formalin fixation on in vitro distensibility of human femoral arteries. Am. Heart J. 125(2):344-349. <http://dx.doi.org/10.1016/0002-8703(93)90010-7> $<$ PMid:8427126>

Queiroz J.E.R. \& Gomes H.M. 2001. Introdução ao processamento digital de imagens. Revta Rita 8(1):1-31.

Ribeiro K.C. \& Shintaku R.C.O. 2004. A influência dos lipídios da dieta sobre aterosclerose. ConScientiae Saúde 3(3):73-83.

Rosa E.M., Kramer C. \& Castro I. 2003. Association between coronary artery atherosclerosis and the intima-media thickness of the common carotid artery measured on ultrasonography. Arq. Bras. Cardiol. 80(6):589-592, 285-288. <http://dx.doi.org/10.1590/S0066-782X2003000600002> $<$ PMid:12856069>

Rosenfield A., Taylor T.K.J. \& Jaffe C.C. 1980. Clinical applications of ultrasound tissue characterization. Radiol. Clin. N. Am. 18(1):31-58. <PMid:7378132>

Saijo Y., Hozumi N., Lee C., Nagao M., Kobayashi K., Oakada N., Tanaka N., Santos Filho E.D., Sasaki H., Tanaka M. \& Yambe T. 2006a. Ultrasonic speed microscopy for imaging of coronary artery. Ultrasonics 44(1 Suppl.1):51-55. <http://dx.doi.org/10.1016/j.ultras.2006.06.050> <PMid:16844175>

Saijo Y., Tanaka A., Iwamoto T., Santos Filho E., Yoshizawa M., Hirosaka A., Kijima M., Akino Y., Hanadate Y. \& Yambe T. 2006b. Intravascular twodimensional tissue strain imaging. Ultrasonics 44(Suppl.1):147-151. <http://dx.doi.org/10.1016/j.ultras.2006.06.049> <PMid:16872653>

Santos W.A. 2017. Estudo morfológico e morfométrico por ultrassonografia modo B do ligamento nucal de equinos da raça Quarto de Milha. Master's Thesis, Faculdade de Medicina Veterinária e Zootecnia, Universidade Estadual Paulista, Botucatu, SP. 60p.

Santos W.G., Monteiro J.N.M., Oliveira D.C., Borlini D.C., Martins-Filho S., Machado F.M., Nunes L. \& Costa F. 2009. Ultrassonografia quantitativa do fígado em gatos com tirotoxicose induzida. Braz. J. Vet. Res. Anim. Sci. 46(6):438-447. <http://dx.doi.org/10.11606/S1413-95962009000600002>

Sarmento P.L.D.F.A., Plavnik F.L., Scaciota A., Lima J.O., Miranda R.B. \& Ajzen A.S. 2014. Relationship between cardiovascular risk factors and the echogenicity and pattern of the carotid intima-media complex in men. São Paulo Med. J. 132(2):97-104. <http://dx.doi.org/10.1590/15163180.2014.1322490><PMid:24714990>

Shaw L.J., Raggi P., Berman D.S. \& Callister T.Q. 2006. Coronary artery calcium as a measure of biologic age. Atherosclerosis 188(1):112-119. <http:// dx.doi.org/10.1016/j.atherosclerosis.2005.10.010> <PMid:16289071> 
Silva E.G., Gonçalves M.T., Pinto S.C., Soares D.M., Oliveira R.A., Alves F.R., Araújo A.V.C. \& Guerra P.C. 2015. Análise quantitativa da ecogenicidade testicular pela técnica do histograma de ovinos da baixada ocidental maranhense. Pesq. Vet. Bras. 35(3):297-303.<http://dx.doi.org/10.1590/ S0100-736X2015000300014>

Smith D.C. 2009. The Book of Mules: selecting, breeding and caring for equine hybrids. The Lyons Press, Connecticut. 136p.

Soares M.Q.S., Castro R.C., Santos P.S.S., Capelozza A.L.A. \& Fischer-Bullen I.R.R. 2015. Contribuição da radiografia panorâmica no diagnóstico de calcificação de ateroma de carótida: relato de caso e revisão da literatura. Revta Port. Estomatol. Med. Dentária Cirurg. Maxilofacial 56(6):127-131.

Souza L.O., Gomes L.P.B., Barbosa V.V., Medeiros G.R., Souza C.M. \& Weller M. 2013. Analysis of the population of equidae in semiarid region of Paraíba. J. Biotechonol. Biodiversity 4(3):269-275.
Sumner D.S. 1990. Use of color-flow imaging technique in carotid artery disease. Surg. Clin. N. Am. 70(1):201-211. <http://dx.doi.org/10.1016/ S0039-6109(16)45045-0><PMid:2406968>

Svicero D.J. 2014. Eficácia do ultrassom na identificação de transplantes de células tronco mesenquimais em tecido muscular equino. Master's Thesis, Faculdade de Medicina Veterinária e Zootecnia, Universidade Estadual Paulista, Botucatu, SP. 71p.

Vescovi L.A., Monteiro J.N.M., Santos W.G.D., Oliveira D.C.D., Borlini D.C. \& Machado F.M. 2009. Ultrassonografia quantitativa do baço de gatos normais. Vet. Foco 7(1):4-10.

Wohlin M., Sundström J., Andrén B., Larsson A. \& Lind L. 2009. An echolucent carotid artery intima-media complex is a new and independent predictor of mortality in an elderly male cohort. Atherosclerosis 205(2):486-491. <http:// dx.doi.org/10.1016/j.atherosclerosis.2009.01.032> <PMid:19243779> 